\title{
The Manager of Providence? Contemporary Catholic Thought Regarding Environmental Problems in the Light of Encyclical Laudato Si'
}

\author{
Thus says the Lord: \\ Heaven is my throne \\ and the earth is my footstool; \\ what is the house that you would build for me, \\ and what is my resting place? \\ All these things my hand has made, \\ and so all these things are mine, \\ says the Lord. \\ Is, 66:1-2
}

The problem of the attitude of Catholic thought towards ecological issues should be considered extremely important - even crucial - for at least two main reasons. The first one is the significance of the environmental concerns themselves. Imbalances in the composition of the atmosphere and the resulting climatic changes are no longer an uncertain hypothesis of small groups of scientists, but the subject of

Bartosz Jastrzębski (ORCID 0000-0002-5904-3000) - a philosopher, a writer, a PhD holder in cultural studies, a professor at the University of Wrocław and a lecturer at the Institute of Journalism and Social Communication of this university. He is interested in philosophy, theology, anthropology and history. Currently, he deals primarily with conservative sociopolitical and religious ideas. 
a general consensus; moreover, fluctuations in climate are observable by the "untrained" eye on the scale of a human lifetime, so without fear of exaggeration it can be said that they are occurring rapidly. Although there are still disputes on the precise extent of human action influencing the global environment, the very fact that the planet is warming is no longer - because it cannot be - questioned. Climate change and atmospheric pollution should be regarded as a major threat today, as they also unleash a whole torrent of detrimental effects, both in the natural and in the socio-political worlds. The endangerment of species (e.g., polar bears), the disappearance of entire ecosystems (e.g., coral reefs), rapid climate zone shifts (no chance for organisms to adapt), sudden changes in groundwater levels, rising sea and ocean levels, melting continental glaciers and mountain glaciers, and weather events which are associated with natural disasters (storms, floods, droughts and fires) are visible and felt even in Poland, despite its fairly privileged geographical location. They all threaten biodiversity, damaging our planet's environment. Even though these events have always occurred, after exceeding a certain limit of intensity and pace, they do not allow animals and plants the opportunity to adapt to the changing conditions.

However, this is only one side of the coin. As mentioned before, these changes also generate adverse effects in the economic, social and political realms. After all, severe droughts, floods of an unprecedented scale and frequency and prolonged seasons of cyclones, typhoons and tornadoes cause deep economic crises, crop failures or even hunger in the countries affected (this particularly applies to sub-Saharan Africa, but also to the Middle East, North Africa or some parts of Brazil, China and India), which, in turn, lead to social and political unrest and even military conflicts (e.g., "water wars"1). Recently, the process of great population movements (the so-called immigration crisis) has also rapidly increased, largely

1 M. Lipowska-Hamdy, A. Synakiewicz, Skad się biora wojny o wode (Where do the water wars come from?), http://www.woda.edu.pl/artykuly/wojny_o_wode/ (access: December 2019). 
triggered - directly or indirectly - by this climate-co-determined destabilisation. Climate change - with its numerous consequences - and the predatory economic policy of strong international players (corporations) bring about a deepening of economic stratification between, in simplified terms, the countries of the populous and poor South, on the one hand, and the prosperous but aging North, on the other. However, as ancient scholars argued, nature seeks to equalise differences in potential, so there has indeed been manifest geopolitical disparity over the past decade, for a variety of reasons, of course, but in this article I want to focus on those caused by ecological conditions.

The Catholic Church, either in its teaching or its practice, cannot ignore these problems or pretend not to notice them at all or act like as if they do not concern it. However, interestingly, although its position seems to be quite doctrinally and theologically clear and unambiguously expressed, in fact, numerous parties to the debates cite Catholic social teachings to justify diametrically different approaches to ecological and environmental problems. In other words, the Church and its teachings (addressed to 1.2 billion believers all around the world - it is still the largest denominational community) are found in the middle of frequently heated ideological and political disputes.

This is the second main reason why I have raised this topic. I would like to take a closer look at the source teaching of the Church in relation to the broadly understood problems of ecology, which is, as we will see, very strongly connected with the totality of its social teaching, including the writings on ownership and the fair distribution and use of goods. Let us note at the beginning that it is characteristic of Catholic thought not to contrast ecology (as "care for animals and plants") with concern for human affairs. On the contrary, integral ecology understood in Catholic terms - as it is based on the theology of creation - encompasses human and non-human creation together, conceptualising it as a dynamic unity (which does not exclude hierarchy). The Catechism addresses this 
issue explicitly and brusquely: "Nothing exists that does not owe its existence to God the Creator. The world began when God's word drew it out of nothingness; all existent beings, all of nature, and all human history are rooted in this primordial event, the very genesis by which the world was constituted and time begun" ${ }^{2}$ (emphasis $\mathrm{BJ})$. Thus, the world of nature is as much a manifestation of God as it is of human history - the world of nature, in part and in whole, is vestigium Dei, God's vestige. And although man is a distinguished being, "creationness" remains the plane of his unity and solidarity with all nature. Detailed, theological and historical tracing of the process of shaping Catholic thought on this subject obviously exceeds the scope of this article. Hence, we will begin our analyses by showing the solidification of "green Catholicism" from the encyclical Rerum Novarum (1879) issued by Leo XIII, and then refer to the documents of the Second Vatican Council, in particular to the Pastoral Constitution Gaudium et Spes (1965), the Catechism of the Catholic Church (1992) and finally to the teachings of recent popes, especially of Francis (Laudato Si', 2015). As a result, we will discover both the presence of permanent elements in the teachings and the emergence of new ones, which are a response to unprecedented occurrences and threats.

Ecology will be understood here in the most rudimentary way, as a science that studies the relationships between living organisms and the abiotic environment (biological systems exist in a network of connections between each other and the surrounding environment), based on various types of interactions. These relationships have been investigated since antiquity, but ecology as an independent science basically developed in the nineteenth century, and for a good reason: it was at this time that the fundamental threats to these relationships and their dysfunctions related to human economic activity became known. For the imbalance of the environment (and its negative impact on the condition of society) was first noticed

2 Catechism of the Catholic Church, para. 338, http://archeparchy.ca/wcm-docs/docs/ catechism-of-the-catholic-church.pdf (access: December 2019). 
in highly urbanised and industrialised areas, such as the coal fields of central England, the Ruhr area and the Netherlands. These negative ramifications manifested themselves not only in the almost complete transformation of the natural environment - along with the loss of many of its valuable assets - but also in displacing large groups of people from their "natural" rural ecosystems, which was associated with the breakup of small, traditional, informal communities, based on direct relationships, and with the onset of mass society: industrial, technologised and becoming more and more bureaucratic over time. These powerful and profound changes have again caused, as is known, the birth of the revolutionary, communist and socialist movements.

The social inequalities which widened due to the development of predatory capitalism, generated - by the law of action-reaction - the demands of decreed property equality or even the abolition of private property. Leo XIII firmly rejects such postulates in his teachings, as does their theological justification:

You cannot $[\ldots]$ defy private ownership of the truth that God gave all mankind the land for use. The fact that God has given the Earth for the use and enjoyment of the whole human race can in no way be a ban on the owning of private property. For God has granted the earth to mankind in general, not in the sense that all without distinction can deal with it as they like, but rather that no part of it was assigned to any one in particular, and that the limits of private possession have been left to be fixed by man's own industry, and by the laws of individual races ${ }^{3}$.

However, the Pope adds:

Moreover, the earth, even though apportioned among private owners, ceases not thereby to minister to the needs of all, inasmuch as there is not one who does not sustain life from what the land produces. Those who do not possess the soil contribute their labor; hence, it may truly be said that all human subsistence is derived either from labor on one's own land, or

3 Rerum Novarum. Encyclical of Pope Leo XIII on Capital and Labor, 15 May 1891, http:// w2.vatican.va/content/leo-xiii/en/encyclicals/documents/hf_l-xiii_enc_15051891_rerum-novarum.html (access: December 2019). 
from some toil, some calling, which is paid for either in the produce of the land itself, or in that which is exchanged for what the land brings forth. Here, again, we have further proof that private ownership is in accordance with the law of nature ${ }^{4}$.

We can clearly see that although Leo XIII strongly rejects the communal possession of land - by perceiving private ownership as the law of nature - he also recognises and emphasises the conditional nature of this ownership. This condition is based on the existence of a deep, metaphysical, God-established bond between man and the land that feeds him, the fruit of which all are guaranteed to have the right to use. In other words, it is based on something more than just natural law, on divine law:

Hence we have the family, the "society" of a man's house - a society very small, one must admit, but nonetheless a true society, and one older than any State. Consequently, it has rights and duties peculiar to itself which are quite independent of the State ${ }^{5}$.

In this fundamental sense, Earth is everyone's property - although we must note that the Pope primarily discusses the right to use it, not yet the responsibility of preserving its resources and condition. The ecology of Rerum Novarum remains, however, for the most part human ecology, in the sense that its subject primarily concerns the relationship of man with his natural and social environment, a relationship strongly disturbed by the emergence and expansion of modern capitalism. That is why the Pope affirmatively states:

Justice, therefore, demands that the interests of the working classes should be carefully watched over by the administration, so that they who contribute so largely to the advantage of the community may themselves share in the benefits which they create - that being housed, clothed and bodily fit, they may find their life less hard and more endurable. It follows that whatever shall appear to prove conducive to the well-being of those who work should obtain favourable consideration. There is no

Ibidem, paras. 8-9.

Ibidem, para. 12. 
fear that solicitude of this kind will be harmful to any interest; on the contrary, it will be to the advantage of all, for it cannot but be good for the commonwealth to shield from misery those on whom it so largely depends for the things that it needs ${ }^{6}$.

Therefore, justice itself is "ecological", because iustitia est habitus secundum quem aliquis constanti et perpetua voluntate ius sum unique tribuit ("Justice is a habit according to which somebody renders to each one his rights by a constant and perpetual will") ${ }^{7}$ and thus also to guarantee every being his or her rightful and proper place in the world. Today we would call this "an ecological niche". Justice is therefore a law of nature and a divine law at the same time. Let's make a note of that.

This conception was maintained and developed in the reflection of the fathers of the Second Vatican Council, and in particular the Pastoral Constitution on the Church in the Modern World, Gaudium et Spes. In this document, we read that:

God intended the earth with everything contained in it for the use of all human beings and peoples. Thus, under the leadership of justice and in the company of charity, created goods should be in abundance for all in like manner. [Likewise] In using them, therefore, man should regard the external things that he legitimately possesses not only as his own but also as common in the sense that they should be able to benefit not only him but also others"

These passages have also been emphasised and commented on in the Catechism:

The right to private property, acquired or received in a just way, does not do away with the original gift of the earth to the whole of mankind. The universal destination of goods remains primordial, even if the promotion of the common good requires respect for the right to private property and

6 Ibidem, para. 29.

Thomas Aquinas, Summa theologiae, II-II, q. 58, a. 1.

8 Gaudium et Spes. Pastoral Constitution on the Church in the Modern World Promulgated by His Holiness, Pope Paul VI on December 7, 1965, para. 69, http://www.vatican.va/archive/ hist_councils/ii_vatican_council/documents/vat-ii_cons_19651207_gaudium-et-spes_ en.html (access: December 2019). 
its exercise [...]. The ownership of any property makes its holder a steward of Providence, with the task of making it fruitful and communicating its benefits to others, first of all his family (emphasis BJ) ${ }^{9}$.

Thus, Earth is a common good, the good of all of us - those who once lived, live today and will live in the future - which also means shared responsibility for it, also from an ecological viewpoint.

This philosophical perspective takes on the deepest meaning in the teachings of Pope Francis, but in this excerpt we can already see that this belief involves a correction of the interpretation of the famous passage from Genesis 1:28, which speaks of letting man have "dominion over the earth". This dominion does not mean a despotic, cruel reign, but being a "steward of Providence", and thus a guardian who "multiplies" its riches, fairly distributes them to others and, by wisely managing them, preserves them for future generations. Let us emphasise this: the biblical dominion does not signify tyranny, the oppression of the weak, injustice, soulless exploitation, disrespect for other creatures or pride and haughtiness - for everything has its value and dignity. The Bible continually reminds us that God harbours hatred for such dominion and inevitably and severely punishes it. After all, the biblical model of every power is He, God, who promises through the mouth of his Servant that "a bruised reed he will not break, and a dimly burning wick he will not quench" (Is 42:3) and "because God did not make death, and he does not delight in the death of the living. For he created all things so that they might exist" (Wis 1:13-14). And in another place, "You spare all things, for they are yours, O Lord, you who love the living. For your immortal spirit is in all things" (Wis. 11:26-12:1).

The psalmist says:

The Lord is good to all, and his compassion is over all that he has made. All your works shall give thanks to you, O Lord, and all your faithful shall bless you. (Ps. 145: 9-10).

Catechism..., paras. 2403-2404. 
So it is a just and gentle rule, based on wisdom, love and joy from the richness of existence. Such is also man's dominion over what has been entrusted to him. The teachings of the Catechism (1992), which John Paul II commissioned and supervised, definitely go in this direction. The doctrine of creation that we find there contains themes present in the Gaudium et Spes Constitution and expands them in a clearly ecological spirit (as we understand this concept today). What provides justification for the claims present in the Catechism is, of course, the category of creation, which implies the original goodness of each creature:

Each of the various creatures, willed in its own being, reflects in its own way a ray of God's infinite wisdom and goodness. Man must therefore respect the particular goodness of every creature, to avoid any disordered use of things which would be in contempt of the Creator and would bring disastrous consequences for human beings and their environment ${ }^{10}$.

Here, for the first time, man and his environment are considered directly together, although the following paragraph (343) sustains the careful distinction between man and the rest of creation in the spirit of the classical theology of creation. However, the emphasis has undoubtedly shifted: the good of man and the good of the environment are closely and inextricably linked, so they can no longer be placed in opposition.

In the paragraphs of interest, there are also categories which are particularly important from an ecological point of view, such as interdependence, variety and diversity. They are unquestionably valued:

God wills the interdependence of creatures, the sun and the moon, the cedar and the little flower, the eagle and the sparrow: the spectacle of their countless diversities and inequalities tells us that no creature is self-sufficient. Creatures exist only in dependence on each other, to complete each other, in the service of each other [...]. The beauty of the universe: the order and harmony of the created world results from the diversity of

10 Catechism..., para. 339. 
beings and from the relationships which exist among them. Man discovers them progressively as the laws of nature. They call forth the admiration of scholars; the beauty of creation reflects the infinite beauty of the Creator ${ }^{11}$.

Therefore, (bio)diversity is a value in itself, because it is deeply rooted in the Divine will, and thus in the architecture of being. The radicalism and distinctiveness of Catholic ontology is expressed in the strong conviction that, since all creation has been saved (also the corporeality and materiality that Christ took upon himself), nothing - none of the things created by God - can die, and indeed nothing dies: everything finds salvation and ultimate refuge in $\mathrm{Him}^{12}$. Creatures transition into another, mysterious form of existence, but they do not disappear. They cannot vanish because it would be some failure of God, a loss of His "possession", which is unthinkable. Both thoughts and bodies last forever in all their wealth, though our sinful and corrupt eyes may not see this.

"I did not lose a single one of those whom you gave me" (John 18:9) says the Word, and the Father gave the Son everything. This affirmation of diversity is a clear nod to the tradition of biblical thought - and Hebrew tradition in general - in which the multitude of creation is a peculiar glory of being and its splendour, as well as an expression of the power of God and the richness of being contained in Him. This approach is visibly different from Greek philosophy, in which again - since the time of Parmenides, at least, if not the Orphics - multiplicity and diversity are usually some form of degradation and

\footnotetext{
11 Ibidem, paras. 340-341.

12 Hans Urs von Balthasar writes beautifully about it: "It is not only some quintessence, an extract of this world that is to enter eternity, something that could be, as the reflection and trace of the world, for example an "immortal soul". It is the real world itself which is to enter eternity, with all the diversity of its content, history, becoming and passing away, with its grandeur et misere, which cannot be separated from each other, because misere is possible only because the grandeur can only be realised in the transient time. This wholeness, as it really exists due to God's providence and the confusion introduced by people, will receive absolution and 'access to the Father' thanks to the grace of Christ". And further on, he writes, "Christ's ascension to heaven is taking with him all of reality of creation and transferring it to God". Translation after Polish edition: H.Uvs. von Balthasar, Eschatologia w naszych czasach (Eschatology in our time), trans. W. Szymona, Kraków: Wydawnictwo WAM, 2008, pp. 72 and 77 .
} 
disintegration of the original Unity, and thus, in some sense, they are evil (at least in the broadly understood Pythagorean-Platonic tradition). By contrast, the Book of Genesis leaves no doubt: "God saw everything that he had made, and indeed, it was very good" (Gen 1:31). If you apply these suppositions to the field of ecology, the conclusions are unambiguous and irresistible: an ecosystem of ten species is "better" than that of five. A senseless loss of the life of every species, and even of every individual, is a depletion of God's creation, a failure to preserve what was entrusted to our protection. So it is a sin and a cause for shame. The Catechism leaves no doubt in this respect: "It is contrary to human dignity to cause animals to suffer or die needlessly"13 and "Animals are God's creatures. He surrounds them with his providential care. By their mere existence they bless him and give him glory. Thus, men owe them kindness"14 (emphasis BJ).

In the other paragraph,in turn, we read, "The hierarchy of creatures is expressed by the order of the 'six days', from the less perfect to the more perfect. God loves all his creatures and takes care of each one, even the sparrow"15. Nevertheless, Jesus said, "You are of more value than many sparrows" (Luke 12:7), or again, "of how much more value is a man than a sheep!" (Mth 12:12). We can see, therefore, that the categorical emphasis on the value of each creature does not tolerate their gradation, and "man is the summit of the Creator's work"16. He is a rational being, bearing not only the vestige of God (vestigium), but also His image (imago), which implies both the rights (to use other beings for his own benefit) and obligations (care and protection of them). Simply put, we eat plants and animals and obtain living space at their expense. In the present condition of the world, this seems inevitable, because it is one of the consequences of the fall of man who brought down all creation with him. That is why

13 Catechism..., para. 2418.

14 Ibidem, para. 2416,

15 Ibidem, para. 342

16 Ibidem, para. 343. 
For the creation waits with eager longing for the revealing of the children of God; for the creation was subjected to futility, not of its own will but by the will of the one who subjected it, in hope that the creation itself will be set free from its bondage to decay and will obtain the freedom of the glory of the children of God (Rom 8: 19-21).

The compulsion to "use" and consume plants and animals should not obscure their existential, natural dignity and the fact that they are sentient beings that, therefore, liberation from corruption and suffering was foreseen for them in God's Providence, and so was, some further, eschatological life: participation in "the freedom of the glory of the children of God". Aquinas had already mentioned this:

In another way the visible is ordained by God to an end which transcends its natural form. For just as the human body will be clothed with the form of supernatural glory, so all visible creation in that glory of the children of God will itself obtain a new glory ${ }^{17}$.

What is characteristic for this form of expression is a sort of uncertainty: "some glory", "some further life". Catholic thought is far from a fixed or dogmatic idea in this area and openly admits it. The author of the dogmatic Traktat o rzeczywistości ostatecznej (Treatise on final reality), Zbigniew Danielewicz, titled the last chapter of his work New Heaven and New Earth - The Eschatology of Non-Human Creation. At the same time, however, he immediately claims in the introduction:

In eschatological studies, such a chapter as this one is slowly beginning to establish its inalienable place. Despite the existence of straightforward biblical premises and the logic of the theology of creation and redemption, eschatology of the cosmos and nature was often treated marginally, it was overlooked or a spiritualistic character was ascribed to it. [...] The alienation of man and nature, deepening in the modern era, where man's dignity grew and nature was considered merely a substance subordinated to man

17 Translated after Polish edition: Św. Tomasz z Akwinu, Wykład Listu do Rzymian (Letter to the Romans: Commentary), trans. J. Salij, Poznań: Wydawnictwo Polskiej Prowincji Dominikanów W Drodze, 1987, p. 129. 
(res cogitans - res extensa), also failed to lead to the recognition of the inherent value of matter and nature, and a reflection on its redemption ${ }^{18}$.

Danielewicz refers openly to the error of modernity (some also talk about the error of Cartesianism), as a result of which nature was "de-deified", i.e., reckoned to be only a lifeless material for unlimited human activity. Contrary to Thomists, the author of the Discourse on Method conceived of animals as automata which are devoid of soul. This, of course, removed all restrictions on the exploitation of non-human creatures and completely alienated human beings from them.

Yet, we are an integral part of the natural world - admits Danielewicz. You can't overlook this. For man as a corporeal being, the entire universe is his environment, and therefore, he cannot attain his fullness without the world attaining fullness. Offering the entire renewed creation, together with the gift of eternal life and eternal looking at God to the resurrected people in the future world will fulfil the promise, "when he comes again in glory and majesty and all is at last made manifest, we who watch for that day may inherit the great promise in which now we dare to hope ${ }^{19}{ }^{20}$.

Protestant Christian philosophy also takes a similar line. Let us recall here the words of the outstanding theologian Jürgen Moltmann, who also strongly rejects the "modern error":

Limiting the Church only to the world of people, and the world of people only to the salvation of the soul was a dangerous modern reduction. But if the Church is oriented towards the universe, then the ecological crisis of the earthly creation will also be the crisis of the Church itself, because as "flesh of flesh and bone of bone" it will be destroyed if the earth is destroyed. The community of creation suffers with each death of weaker creatures. If the Church sees itself as a representative of creation, then the suffering of weaker creatures also becomes painful for the Church and it must openly

\footnotetext{
18 Z. Danielewicz, „Traktat o rzeczywistości ostatecznej” (Treatise on final reality), Dogmatyka 2006, vol. 6, p. 494.

19 Preface I on Advent. The Two Comings of Christ, Missal, i-Breviary, http://www.ibreviary. $\mathrm{com} / \mathrm{m} / \mathrm{messale}$.php?s=prefazio\&id=89 (access: December 2019).

20 Z. Danielewicz, „Traktat...”, p. 494-495.
} 
scream from this pain. Not only does our "human environment" suffer, but also the creation that was made as "God's environment" suffers as well ${ }^{21}$.

This apparently rather radical belief of the Protestant thinker is, however, confirmed and upheld in the teachings of Pope Francis. His encyclical Laudato Si' is the first papal document of this rank devoted entirely to the problems of ecology. Already in the introduction to this document, the Pope appreciatively quotes the words of the Ecumenical Patriarch and Archbishop of Constantinople Bartholomew I:

For human beings $[\ldots]$ to destroy the biological diversity of God's creation; for human beings to degrade the integrity of the earth by causing changes in its climate, by stripping the earth of its natural forests or destroying its wetlands; for human beings to contaminate the earth's waters, its land, its air, and its life - these are sins". For "to commit a crime against the natural world is a sin against ourselves and a sin against God ${ }^{22}$.

Francis strongly condemns this predatory approach to nature, and locates its roots in destructive, greedy consumerism:

But a sober look at our world shows that the degree of human intervention, often in the service of business interests and consumerism, is actually making our earth less rich and beautiful, ever more limited and grey, even as technological advances and consumer goods continue to abound limitlessly. We seem to think that we can substitute an irreplaceable and irretrievable beauty with something which we have created ourselves ${ }^{23}$.

So again the eternal temptation arises here - we will be as gods, we will create for ourselves a world far better, more comfortable and more beautiful than the one we found and in which we are toiling today. It cannot be denied that excessive pillaging of the earth was so far motivated by the need to remedy human poverty only to a small

\footnotetext{
${ }_{21}$ Translated after Polish edition: J. Moltmann, Bóg $w$ stworzeniu (God in creation), trans.

Z. Danielewicz, Kraków, Wydawnictwo Znak, 1995, p. 531.

22 Laudato Si'. Encyclical Letter of the Holy Father Francis on Care for Our Common Home, 24 May 2015, para. 8, http://www.vatican.va/content/francesco/en/encyclicals/documents/ papa-francesco_20150524_enciclica-laudato-si.html (access: December 2019).

${ }_{23}$ Ibidem, para. 34.
} 
extent, while to a large extent it was caused by the greed and avarice of those who possess much and are not at risk of poverty. It is not the poorest peoples and tribes, but the economies and concerns of the world's richest countries that are largely responsible for the destruction of nature. These entities strive for a further increase in the ownership of Western societies. The latter adopted the Enlightenment model of "the intra-world salvation", based on the belief that they could liberate themselves from physical and moral evil through increasing material and economic wealth. And although the bankruptcy of this model is more and more obvious, it still holds true in the Western world. Having rejected God, we want to do what the previous ages saw possible only in the power of God's intervention, that is, to overcome evil and create a new, wonderful world.

Meanwhile, however, the Pope reminds us:

We are not God. The earth was here before us and it has been given to us. This allows us to respond to the charge that Judaeo-Christian thinking, on the basis of the Genesis account which grants man "dominion" over the earth (cf. Gen 1:28), has encouraged the unbridled exploitation of nature by painting him as domineering and destructive by nature. This is not a correct interpretation of the Bible as understood by the Church (emphasis BJ). Although it is true that we Christians have at times incorrectly interpreted the Scriptures, nowadays we must forcefully reject the notion that our being created in God's image and given dominion over the earth justifies absolute domination over other creatures. The biblical texts are to be read in their context, with an appropriate hermeneutic, recognising that they tell us to "till and keep" the garden of the world (cf. Gen 2:15). "Tilling" refers to cultivating, ploughing or working, while "keeping" means caring for, protecting, overseeing and preserving. This implies a relationship of mutual responsibility between human beings and nature ${ }^{24}$.

\footnotetext{
24 Ibidem, para. 67. The problem of the alleged responsibility of the Judeo-Christian tradition for the ecological crisis has been the subject of debate and controversy for at least half a century. This was largely due to an article by Lynn White, Jr. "The Historical Roots of Our Ecologic Crisis", Science, 10 March 1967, vol. 155, pp. 1203-1207. The author's main thesis is based on the famous words "let mankind have dominion". The encyclical of Pope Francis can then be treated as a voice in this discussion, a voice indicating that the ecological attitude is deeply rooted in the biblical and theological tradition.
} 
Therefore, the essence of human dominion is completely different according to Catholic thought. It is involves cultivating the "garden of the world", ensuring that it reaches perfection, that higher and full form which it fairly deserves, because it is assigned to it in the plan of Providence, and it does not involve a demonic manipulation of the architecture of being according to one's own uncertain and risky ideas in order to fulfil one's various - often bizarre and sick fantasies. Indeed, people are rather "settlers" and "leaseholders" of the earth rather than its owners. This thought should guide man in regulating and shaping his attitude towards creation. Pope Francis explains:

Each community can take from the bounty of the earth whatever it needs for subsistence, but it also has the duty to protect the earth and to ensure its fruitfulness for coming generations. "The earth is the Lord's" (Ps 24:1); to him belongs "the earth with all that is within it" (Dt 10:14). Thus, God rejects every claim to absolute ownership: "The land shall not be sold in perpetuity, for the land is mine; for you are strangers and sojourners with me" (Lev 25:23) 25 .

Hence, the earth remains a common good - which is an absolutely basic assumption - granted to all people for sound management. As part of this sound management, there is undoubtedly a concern for the climate, the condition of the water and the vegetation, air quality, the welfare of plant and animal species and leaving the planet's resources in such a state that will allow future generations to survive. "An integral ecology is inseparable from the notion of the common good, a central and unifying principle of social ethics", states Francis ${ }^{26}$. This common good, however, consists not only of the natural environment, but also of the reality of specific historical, artistic and cultural traditions. Therefore, one should not build an antithesis between the good of nature and the good of culture (based on a pop-journalistic, not very sophisticated principle: "either man,

Laudato Si'..., para. 67.

26 Ibidem, para. 157. 
or frogs and birds"), but to include them together as part of the project described by the Pope as integral ecology:

Ecology, then, also involves protecting the cultural treasures of humanity in the broadest sense. More specifically, it calls for greater attention to local cultures when studying environmental problems, favouring a dialogue between scientific/technical language and the language of the people ${ }^{27}$.

Because, as the Pope adds, "the disappearance of a culture can be just as serious, or even more serious, than the disappearance of a species of plant or animal" 28 , building a strict opposition between the good of historical communities and the well-being of the natural environment is incorrect and is not in line with Catholic tradition. In light of all the above statements of the Magisterium, as well as in light of common sense, it can clearly be seen that these realities are inextricably linked and it is impossible to think about the duration, and even more the development of a given community in a degraded, sterilised and dead environment.

Thus, contrasting ecology with Catholicism, or vice versa, has no dogmatic, theological or philosophical basis: it is a purely rhetorical and political manoeuvre. Left-wing movements have quite efficiently - one must admit - "won back" pro-ecological positions from those backgrounds in which they actually emerged, i.e., conservative and right-wing movements, including Catholic ones. Catholicism is, and must be, deeply ecological - although this necessity was not always well-exposed (but, admittedly, circumstances did not require it). This is clear from both biblical testimonies sanctioning the value of each being and the philosophy of Tradition within the theology of creation. Similarly, in this context, there are no grounds for invoking "the holy right to property" (which some conservative liberals and "libertarians" do so willingly) to justify the robbery and destruction of nature. We have seen that within Catholic teaching the right to property is by no means sacred, but conditional, and does not absolve one from treating property as a common good. 
This does not mean, of course, that Catholic teaching promotes the formal and legal restrictions on the right to property in any way - such ideas have been repeatedly and strongly rejected by the Church. Restrictions on the right to property are of a moral nature: they are a demand for justice and responsibility. At the same time, this is an expression of anthropological realism: We, all individual people, are dying, entire families and nations are also dying out, while land, air and water remain. We are obliged to respect this. We have also seen that making an opposition between the good of nature to the good of human communities makes no sense. Only extremely shallow and superficial thinking can construct and refer to such oppositions. In general, it is not thinking at all, but only an attempt to create ad hoc justifications for obtaining easy income at the expense of the environment. With the current population of our planet, no-one can perceive themselves and their property as absolutely autonomous. We will be able to meet most of the most serious challenges related to environmental changes only if we understand our shared responsibility for all living beings together with their entire environment.

\section{References}

Catechism of the Catholic Church, http:/ / archeparchy.ca/wcm-docs / docs/catechism-of-the-catholic-church.pdf.

Danielewicz Z., "Traktat o rzeczywistości ostatecznej” (Treatise on final reality), Dogmatyka 2006, vol. 6.

Gaudium et Spes. Pastoral Constitution on the Church in the Modern World Promulgated by His Holiness, Pope Paul VI on December 7, 1965, http://www.vatican.va/archive/hist_councils/ii_vatican_ council/documents/vat-ii_cons_19651207_gaudium-et-spes_ en.html.

Laudato Si'. Encyclical Letter of the Holy Father Francis on Care for Our Common Home, 24 May 2015, http://www.vatican.va/content/ francesco/en/encyclicals/documents/papa-francesco_20150524_ enciclica-laudato-si.html. 
Lipowska-Hamdy M., Synakiewicz A., Skąd sie biora wojny o wode (Where do the water wars come from?), http://www.woda.edu.pl/ artykuly/wojny_o_wode/.

Moltmann J., Bóg $w$ stworzeniu (God in creation), trans. Z. Danielewicz,Kraków: Wydawnictwo Znak, 1995.

Rerum Novarum. Encyclical of Pope Leo XIII on Capital and Labor, 15 May 1891, http://w2.vatican.va/content/leo-xiii/en/encyclicals/documents/hf_1-xiii_enc_15051891_rerum-novarum.html.

[Św.] Tomasz z Akwinu, Wykład Listu do Rzymian (Letter to the Romans. Commentary), trans. J. Salij, Poznań: Wydawnictwo Polskiej Prowincji Dominikanów W Drodze, 1987.

Urs von Balthasar H., Eschatologia w naszych czasach (Eschatology in our time), trans. W. Szymona, Kraków: Wydawnictwo WAM, 2008.

White Lynn, Jr., "The Historical Roots of Our Ecologic Crisis", Science, 10 March 1967.

\section{The Manager of Providence? Contemporary Catholic Thought Regarding Environmental Problems in the Light of Encyclical Laudato si'}

Opposing ecology to Catholicism, or vice versa, has no dogmatic, theological or philosophical foundations - it is a purely rhetorical and political maneuver. Catholicism is, and must be, deeply ecological although this necessity has not always been properly displayed (but it should also be admitted that circumstances did not require this). This is clearly evidenced by both biblical testimonies confirming the value of every being and the reflection of Tradition within the theology of creation. Similarly, in this context, there are no grounds for invoking the "holy property right" (as some conservative liberals and "libertarians" are willing to do) to justify the robbery and destruction of nature. Within the Catholic doctrine, property law is by no means holy, only conditional, and does not absolve us from treating property as a common good at the same time. Of course, this does not mean that Catholic teaching promotes in any way formal and legal restrictions on the right to property - such ideas have been repeatedly and decisively rejected by the Church. The limitation of the right of ownership is moral here - it is a postulate of justice and responsibility. At the same time, it is an expression of anthropological 
realism: we, all individual people, die, all families and nations expire and the earth, air and water remain. We are obliged to respect it. Opposing the good of the environment to the welfare of human communities makes no sense. Only extremely shallow and superficial reflection can build and invoke such oppositions. In general, this is not a reflection at all, but only an attempt to create ad hoc justifications for obtaining an easy income at the expense of the environment. With the current population of our planet, no one can perceive themselves or their immovable property as absolutely autonomous. We will be able to meet most of the most serious challenges related to environmental changes only when we understand our own responsibility for all living creatures along with their and our entire environment.

Keywords: creation, environment, Catholicism, Catholic social teaching, ecology, integral ecology, justice, eschatology of non-human creation, common good, property right. 